\title{
The Nuts and Bolts of High Tunnel Production and Manipulation for Specialized Applications: Introduction to the Workshop
}

\author{
Fumiomi Takeda ${ }^{1,3}$ \\ USDA-ARS, Appalachian Fruit Research Station, 2217 Wiltshire Road, Kearneysville, WV 25430 \\ Penelope Perkins-Veazie ${ }^{2}$ \\ USDA-ARS, South Central Agricultural Research Laboratory, P.O. Box 159, Lane, OK 74555
}

Additional index words. high tunnel, microenvironment, foodborne pathogens, LED, netted shade covering, soil amendment, protected agriculture, season extension

Protected agriculture in plastic film structures started after World War II with the advent of polyethylene sheets. In 1999, greenhouse and high tunnel production was reported to be 800,000 ha worldwide (Lamont, 2005). China, Japan, and the Mediterranean region lead in protected environment agriculture. In the United States, interest in high tunnels has surged since 1990. Today, crops are grown under high tunnels in 45 states and high tunnel research and demonstration projects have been established in 37 states (Carey et al., 2009). High tunnels and other plastic film-covered structures are used to improve the crop environment by sheltering plants from wind and rain, diffusing light, excluding animal and insect pests, extending the harvest season, and improving crop quality and yield. Also, rainfall protection provided by plastic covering decreases incidence of foliar and fruit diseases. The increased elevation in air and soil temperatures and diffused lighting realized in high tunnels in early spring and fall accelerate plant growth and crops to be harvested earlier in spring while extending harvest in late fall. Although winter production in unheated high tunnels may be curtailed by cold air temperature in some regions, the warmer soil temperature may permit overwintering or early planting of some crops. Cropping under a protected environment may not be economically feasible in all production regions of the United States because of the high cost $(\approx \$ 80,000 /$ ha; Haygrove Tunnels, Elizabethtown, PA) of high tunnels and/or environmental constraints.

This workshop on the practical aspects of high tunnel production was held at the 2008 ASHS Annual Conference in Orlando, FL, and organized by the Viticulture and Small Fruit Working Group. Many papers on high tunnel production published in ASHS publications have dealt with structure designs, construction techniques, types of crops, and cropping systems, but information on the possible enhancement of phytonutrient contents or foodborne pathogens of crops grown in high tunnels is not well documented. High tunnels affect environmental factors such as temperature, irradiance level, and wind, which impact plant growth rate and development; however, minimal attention has been given to spatial microclimate variations in high tunnels throughout the growing season or as plant canopy volume increases. More information is needed about the benefits of high tunnel cropping systems and new production technologies for environmental manipulation to improve food safety, quality of fruits and vegetables, and plant productivity.

Although plant response to light levels and spectral quality are well documented, types of lighting for use in high tunnel systems continue to evolve. Plastic coverings and shade netting materials provide a means to modify the light spectral quality to affect crops grown in high tunnels. High-pressure sodium and fluorescent lamps to supplement natural light are commonly used in greenhouses to increase light intensity and photoperiod, but they are impractical in high tunnels. Alternative supplemental lighting systems may include low-output light-emitting diodes (LEDs). LEDs are lower priced, small, and have narrow bandwidth illumination spectra. They can be used in high tunnel cropping systems to influence plant morphogenesis such as internode length, branching, flower initiation, and flower development.

A protected environment production system may alter phytochemical content of fruits and vegetables because of selected light wavelength and quantity through the plastic covering, whereas reduced transmission of ultraviolet light can affect microbial population. If composted organic matter and raw animal manure are incorporated as soil amendments, pathogen contamination and spread of foodborne illness could become a possibility. High tunnel production systems should improve regional production of specialty crops to meet consumer demand for fresh, high-quality, locally grown fruits and vegetables by shortening the time lapse between harvest and consumption.

Specifically, each of the four speakers in this workshop described practical innovations and technologies for manipulating the high tunnel microenvironment to improve food safety, quality of fruits and vegetables, and plant productivity. The following four papers summarize the pertinent literature and provide new information on issues related to food safety, temperature distribution in high tunnels during the growing season, modification of light spectral quality with cloth coverings and LED and other aspects of plant morphogenesis in horticultural crops. The specific topics presented in these papers include: 1) effects of organic soil amendment practices in high tunnels on strawberry phytonutrient contents and on vegetable quality and potential for resulting contamination from enteric pathogens at the primary field production stage; 2 ) three-dimensional analysis of temperature distribution within the high tunnel throughout the growing season and its implication on crop production; 3) effects of colored shade netting material on the quality of horticultural crops; and 4) manipulation of light environment with LED to control flowering and morphogenesis of herbaceous plants.

\section{Literature Cited}

Carey, E.E., L. Jett, W.J. Lamont, Jr., T.T. Nennich, M.D. Orzolek, and K.A. Williams. 2009. Horticultural crop production in high tunnels in the United States-A snapshot. HortTechnology 19:37-43

Lamont, W.J., Jr. 2005. Plastics: Modifying the microclimate for the production of vegetable crops. HortTechnology 15:477-481. 